\title{
Smartphone Medical Apps Use by Health Professionals: Is Gender a Confounding Factor?
}

\author{
Elena J. Tetenova ${ }^{1}$, Aleksei V. Nadezhdin ${ }^{1,2}$, Alexey J. Kolgashkin ${ }^{1}$, Mikhail V. Fedorov ${ }^{1}$, Inessa A. Bedina ${ }^{1}$, \\ Egor A. Koshkin ${ }^{3}$, Sergei V. Zolotukhin ${ }^{1}$, Alexandr I. Klyachin ${ }^{1}$, Valery V. Shipitsin ${ }^{1}$, Yelena I. Sokoltchik ${ }^{1}$, \\ Evgeniya A. Koshkina ${ }^{1}$, Sergei G. Koporov ${ }^{1} \&$ Evgeny A. Bryun ${ }^{1,2}$ \\ ${ }^{1}$ Moscow Research and Practical Centre for Narcology, 37/1 Lyublinskaya Ulitsa, Moscow, Russia \\ ${ }^{2}$ Russian Medical Academy of Continuous Professional Education, 2/1 Barrikadnaya Ulitsa, Moscow, Russia \\ ${ }^{3}$ I.M. Sechenov First Moscow State Medical University, 8 Trubetskaya Ulitsa, Moscow, Russia
}

Correspondence: Alexey J. Kolgashkin, Moscow Research and Practical Centre for Narcology, 37/1 Lyublinskaya Ulitsa, Moscow 109390, Russia. E-mail: ajkol@narcologos.ru

Received: December 28, 2021 Accepted: February 9, 2022 Online Published: February 17, 2022

doi:10.5539/gjhs.v14n3p87

URL: https://doi.org/10.5539/gjhs.v14n3p87

\begin{abstract}
The main aim of the study was to establish, whether the gender of a health professional affects the use of smartphone medical apps. We studied the basic patterns of smartphone use in doctors with the largest addiction clinic in Moscow, engaged in in-patient treatment, to access possible gender-determined "digital divide", evaluate the current use of medical applications, and eventual intentions to use a decision-support app. We performed a cross-sectional study of a non-probability sample of medical doctors using a non-standardized anonymous self-questionnaire, covering 3 domains: socio-demographic and professional characteristics; present use of a mobile device; attitudes to the use of mobile medical apps. The study covered 212 of the 328 staff members, $56 \%$ men and $44 \%$ women. The largest age group was $41-50$ years old $(32.1 \%)$, followed by $51-60(25 \%), 31-40$ $(23.6 \%)$, over $61(10.8 \%)$ and $20-30(8.5 \%) .77 .8 \%$ of respondents use mobile Internet in the office to search for professionally relevant information. $86.5 \%$ would like to use mobile applications that help in their professional activities. We failed to confirm the hypothesis about possible gender-related features in the use of mobile devices in doctors. The dedicated mobile system for supporting clinical decision-making in addiction hospitals may be in-demand. The level of doctors' use of mobile devices and mobile applications shows the absence of gender barriers to the utilization of such systems. In the future, we recommend studying other socio-demographic and occupational predictors affecting the use of professional mobile applications by health professionals of various specialties and the acceptability of the gaming approach in the field.
\end{abstract}

Keywords: digital divide, smartphone, mobile application, gender

\section{Background}

The introduction of modern digital technologies in healthcare is currently considered one of the most important tools to improve the quality and accessibility of medical care. Great attention is paid to this by WHO (WHA 71.7 26 May 2018) (WHO, 2019). Today we have two principal elements to facilitate the process - these are clinical decision support systems (CDSS) and smartphones.

O'Sullivan defined the concept of CDSS as: "a system that provides the clinician or patient with computer-generated clinical data or patient-related information that has been rationally selected and presented at the right time to improve patient care." CDSS appeared over 50 years ago, but are still used in medical practice only on a limited scale. This is due to the need to process large volumes of high-quality data, digitize this data, as well as harmonize the principles of information processing by the system and existing practices of a particular medical institution (O'Sullivan et al., 2014).

In a systematic review, Khariat indicates that the introduction of CDSS in clinical practice is hampered by the fact that these systems were often developed without taking into account the opinions of practitioners and did not reflect the decision-making process (Khairat et al., 2018).

In 2003, the chapter "The Digital Divide and What to Do About It" by E. Hargittai was published in the New Economy Handbook. There the digital divide was defined as the inequality in access and use of the digital 
environment, which is less used by women, ethnic minorities, people with low incomes and education, residents of rural areas, and older age groups (Hargittai, 2003). Hong noted that, despite the sharp increase in the availability of Internet technologies and related mobile devices in the last decade, the digital divide problem has not only not disappeared, but has acquired a new form - digital inequality. The question was no longer whether the user has access to the Internet, but whether he knows how to use it (Hong et al., 2017).

To the best of our knowledge, the number of studies on the digital divide and the digital inequality among health professionals, including doctors, is insignificant. Usually, one studies the very fact of the availability of smartphones and Internet access in remote and rural areas of underdeveloped countries (Shiferaw \& Mehari, 2019; Yagos et al., 2017). At the same time, we met several works on the readiness of health professionals to work in the digital environment. In 2017, Albrecht conducted a comparative study of the use of mobile devices and related applications by doctors and ambulatory patients, depending on their socio-demographic parameters, such as age, education, gender, professional experience, concluding that the advantages of digital technologies are underused, both by doctors and patients (Albrecht et al., 2017).

The gender issues in the professional style of health professionals have been the subject of several studies. For example, Tsugava found that older patients who were treated by female doctors were less likely to be re-hospitalized and die than patients of male doctors (Tsugawa et al., 2017). The frequency of re-hospitalization depending on the gender of the doctor was also considered (Skolka et al., 2020). It was noted that women doctors are distinguished by a more patient-oriented approach: they communicate more with patients and devote more time to them (Roter et al., 2002).

At the same time, there is a certain lack of knowledge concerning the influence of gender on patterns of attitude to and use of e- and mHealth technologies among health professionals.

In the article, we focused on a rather narrow aspect - the study of gender differences in the use of a smartphone both as a means of communication and a possible platform for CDSS by doctors working in the largest addiction clinic in Moscow

\subsection{Aims and Objectives of the Study}

The aim is to study the gender differences in the main patterns of smartphone use as a means of communication and access to the media, including in the professional activities among doctors providing in-patient care in an addiction clinic.

The objectives of the study were to answer the following research questions:

Is the gender-related phenomenon of the "digital divide" / "digital inequality" present or absent in health professionals?

Is there a gender difference in the use of medical smartphone applications by doctors and what are their attitudes to such use in the future?

Are there any gender differences in doctors' preferences for the integral components of such applications?

\section{Materials and Methods}

\subsection{Study Design}

A cross-sectional study of a non-probability sample of doctors from the Moscow Scientific and Practical Center for Narcology (Center), working in three departments of the Center providing in-patient addiction treatment, was carried out. The study was approved by the local ethics committee of the Center (Protocol No. 3/18 of November 26, 18) and was conducted in March-April 2019.

\subsection{Inclusion in the Study}

Medical doctors of various specialties working in a hospital were invited to participate. Participation was voluntary. Remuneration of respondents was not provided, the fact of filling out the questionnaire was considered as consent to participate.

\subsection{Research Tool}

The non-standardized anonymous self-reporting questionnaire was developed by the authors. When developing it we used the provisions, expressed in (Jones et al., 2013; Rea L.M. \& Parker R.A., 2014). In our view, it reflects the situation in which medical doctors find themselves in the digital environment. It consisted of 20 items covering 3 domains: individual socio-demographic and professional characteristics (4 items), current use of a mobile device (13 items), attitude to the use of mobile medical applications (3 items) (Appendix 1). Some of the questions 
provided for a dichotomous, and some - multiple answers with the possibility to select all the proposed options, two items provided fields for free answers. The questionnaires were distributed during weekly clinical conferences in the respective inpatient departments. The doctors were provided with brief oral information on the study itself and the questionnaire. The completed questionnaires were collected by a member of the research team and assigned registration numbers, in which the number of the inpatient department and the serial number of the questionnaire were encoded. The data of the questionnaires were entered into a specially developed database, implementing the "double-entry" method with the subsequent correction of the detected errors. The basic principles of organizing information and technical support for the study were presented in our article (Nadezhdin A.V., 2018).

\subsection{Statistical analysis}

The data were analyzed using IBM SPSS 25.0 (Armonk, NY). We considered p-value of $<0.05$ significant. Confidence intervals (95\%) for proportions were calculated using the Wilson method applying Statclass software add-on (Predictive Solutions, Russia, Moscow) for IBM SPSS. To identify differences between categorical variables, the Pearson $\chi^{2}$ test was used, and in the case of $2 \times 2$ tables with Yates correction for continuity. To determine the strength of association between two nominal or nominal and an ordinal variable we used Cramer's V. The interpretation of the values was carried out according to the recommendations of Rea \& Parker $(.00$ and under .10 - negligible association, .10 and under .20 - weak association, .20 and under .40 - moderate association, .40 and under .60 - relatively strong association, .60 and under .80 - strong association, .80 and under 1.00 - very strong association) (Rea L.M. \& Parker R.A., 2014).

Multivariate questions were considered as a set of univariate variables, indicating answer options. In other words, each answer option was presented as a dichotomous variable.

The sample size for the study was calculated using GPower 3.1.9.7 package with effect size $=0,3 ; \alpha=0.05$; power $=0.95 ; \mathrm{df}=2$, giving total sample size of 172 .

\section{Results}

The characteristics of the respondents are presented in Table 1.212 of the 328 staff members of the Center who met the inclusion criteria participated in the study, $24.1 \%$ of participants represented the Center; $46.7 \%$ Clinical Branch No. 1; 29.2\% - Clinical Branch No. 2. The gender division among respondents was $56 \%$ men and $44 \%$ women. The largest age group was $41-50$ years old (32.1\%), followed by 51-60 (25\%), 31-40 (23.6\%), over 61 (10.8\%) and $20-30(8.5 \%)$ years. According to the specialties, participants were distributed as follows: $77.4 \%$ addiction doctors, $14.6 \%$ doctors of other specialties, $5.7 \%$ anesthetists-resuscitators, $1.4 \%$ psychotherapists, $0.9 \%$ psychiatrists. $81.1 \%$ of the sample worked as resident doctors and $18.9 \%$ as department heads. Of the doctors interviewed, only 1 denied use of mobile communications, which amounted to $0.5 \%$ of the sample (for this reason, this case was excluded from further analysis). Of the doctors surveyed, $67 \%$ own mobile phones with the Android operating system, $21 \%$ use iOS, $12 \%$ use devices with other operating systems. To the question "Do you use mobile Internet" $89.6 \%$ gave an affirmative answer. The overwhelming majority of survey participants (70.9\%) reported that they use one SIM card, $26.7 \%$ - two, $2.4 \%$ - three.

Table 2 presents the gender distribution of answers to the multivariate question "Do you use a mobile phone for ...". It shows that differences were detected only in 2 cases. Affirmatively answered the question "Do you use the phone to listen to music" $35.0 \%$ of men and only $16.3 \%$ of women (the strength of association is moderate). Men also used their phones more often to watch video content $30.8 \%$ versus $15.2 \%$ (the strength of association is weak).

Table 3 presents the gender distribution of answers to the multivariate question "For you, a mobile phone is ...". Here two differences are evident: women more often consider a smartphone as a means of everyday communication: $93.5 \%$ versus $82.9 \%$ for men (the strength of association is weak), and men more often use the gadget as a means of entertainment $21.4 \%$ against $9.8 \%$ for women (the strength of association is weak).

Table 4 presents data on the distribution of respondents' answers to several questions from our questionnaire, testing the hypothesis of possible gender differences in the use of mobile devices among doctors. There were no statistically significant differences between men and women in the answers to the vast majority of questions presented in the table, including items that were significant for the present study, such as the use of the Internet during office hours to search for professionally valid information; availability on a smartphone medical applications; intention to use similar applications in the future. It was also found that men spend much more time on the use of entertainment content. Answers to the question "How much time do you spend daily using multimedia features?" showed that $68.8 \%$ of men and $90.7 \%$ of women used those functions less than 1 hour daily. If we look at ranges of 1-2 hours and more than 2 hours, the performances of men were significantly higher: $22.9 \%$ 
and $5.8 \%$ and $8.3 \%$ and $3.5 \%$, respectively (the strength of association is moderate).

Table 1. Descriptive characteristics of the study sample

\begin{tabular}{|c|c|c|c|}
\hline \multirow{2}{*}{ Variable } & \multirow{2}{*}{$\begin{array}{l}\text { Total } \\
\text { N (\% within category) }\end{array}$} & \multicolumn{2}{|c|}{$95 \% \mathrm{CI}$} \\
\hline & & Lower limit & Upper limit \\
\hline \multicolumn{4}{|c|}{ Inpatient department of the Center } \\
\hline Head Office & $51(24,1)$ & 0,188 & 0,3049 \\
\hline Clinical Branch № 1 & $99(46,7)$ & 0,401 & 0,5341 \\
\hline Clinical Branch № 2 & $62(29,2)$ & 0,2354 & 0,357 \\
\hline \multicolumn{4}{|l|}{ Gender } \\
\hline Male & $117(56)$ & 0,4896 & 0,6277 \\
\hline Female & $92(44)$ & 0,3746 & 0,508 \\
\hline \multicolumn{4}{|l|}{ Age } \\
\hline 20-30 & $18(8,5)$ & 0,0544 & 0,1302 \\
\hline $31-40$ & $50(23,6)$ & 0,1837 & 0,2973 \\
\hline $41-50$ & $68(32,1)$ & 0,2616 & 0,3863 \\
\hline $51-60$ & $53(25,0)$ & 0,1965 & 0,3124 \\
\hline$\geq 61$ & $23(10,8)$ & 0,0734 & 0,1575 \\
\hline \multicolumn{4}{|l|}{ Doctors (by profession) } \\
\hline Addiction Doctors & $164(77,4)$ & 0,7127 & 0,8248 \\
\hline Psychotherapists & $3(1,4)$ & 0,0048 & 0,0408 \\
\hline Psychiatrists & $2(0,9)$ & 0,0026 & 0,0337 \\
\hline Resuscitation Anesthetists & $12(5,7)$ & 0,0327 & 0,0963 \\
\hline Other professions & $31(14,6)$ & 0,1049 & 0,2 \\
\hline \multicolumn{4}{|l|}{ Doctors (by appointments) } \\
\hline Department Head & $40(18,9)$ & 0,1417 & 0,2467 \\
\hline Resident Physician & $172(81,1)$ & 0,7533 & 0,8583 \\
\hline \multicolumn{4}{|c|}{ Use of mobile communications } \\
\hline Use & $211(99,5)$ & 0,9738 & 0,9992 \\
\hline Do not use & $1(0,5)$ & 0,0008 & 0,0262 \\
\hline \multicolumn{4}{|c|}{ Mobile phone operating system } \\
\hline Android & $140(67,0)$ & 0,6036 & 0,7301 \\
\hline iOS & $44(21,0)$ & 0,1607 & 0,2707 \\
\hline Other & $25(12,0)$ & 0,0823 & 0,1706 \\
\hline
\end{tabular}


Table 2. Gender distribution of answers to the multivariate question "Do you use your mobile phone for ..." *

\begin{tabular}{|c|c|c|c|c|}
\hline Variable & $\begin{array}{l}\text { Men } \\
\text { N (\% within } \\
\text { category) }\end{array}$ & $\begin{array}{l}\text { Women } \\
\text { N (\% within } \\
\text { category) }\end{array}$ & $\chi 2 ;$ df; p-value $* *$ & $\begin{array}{l}\text { Cramer's } \\
\text { p-value }\end{array}$ \\
\hline Communication with colleagues & & & 0,$532 ; 1 ; 0,466$ & 0,$071 ; 0,304$ \\
\hline Yes & $112(95,7)$ & $85(92,4)$ & & \\
\hline No & $5(4,3)$ & $7(7,6)$ & & \\
\hline Communication with clients & & & 0,$041 ; 1 ; 0,839$ & 0,$025 ; 0,723$ \\
\hline Yes & $37(31,6)$ & $27(29,3)$ & & \\
\hline No & $80(68,4)$ & $65(70,7)$ & & \\
\hline $\begin{array}{l}\text { Communication with relatives } \\
\text { and friends }\end{array}$ & & & $<0,000 ; 1 ; 1(0,733)^{* * *}$ & 0,$024 ; 0,728$ \\
\hline Yes & $113(96,6)$ & $88(95,7)$ & & \\
\hline No & $4(3,4)$ & $4(4,3)$ & & \\
\hline $\begin{array}{l}\text { Search for information on the } \\
\text { Web }\end{array}$ & & & 0,$534 ; 1 ; 0,465$ & 0,$062 ; 0,369$ \\
\hline Yes & $88(75,2)$ & $74(80,4)$ & & \\
\hline No & $29(24,8)$ & $18(19,6)$ & & \\
\hline Social Media Communication & & & $<0,000 ; 1 ; 1$ & 0,$005 ; 0,941$ \\
\hline Yes & $40(34,2)$ & $31(33,7)$ & & \\
\hline No & $77(65,8)$ & $61(66,3)$ & & \\
\hline Listening to music & & & 8,$289 ; 1 ; 0,004 * * * *$ & 0,$210 ; 0,002$ \\
\hline Yes & $41(35,0)$ & $15(16,3)$ & & \\
\hline No & $76(65,0)$ & $77(83,7)$ & & \\
\hline Playing games & & & 1,$776 ; 1 ; 0,183$ & 0,$110 ; 0,111$ \\
\hline Yes & $12(10,3)$ & $4(4,3)$ & & \\
\hline No & $105(89,7)$ & $88(95,7)$ & & \\
\hline Watching videos & & & 6,$016 ; 1 ; 0,014 * * * *$ & 0,$181 ; 0,009$ \\
\hline Yes & $36(30,8)$ & $14(15,2)$ & & \\
\hline No & $81(69,9)$ & $78(84,8)$ & & \\
\hline Reading texts & & & $<0,000 ; 1 ; 1$ & $<0,000 ; 0,996$ \\
\hline Yes & $56(47,9)$ & $44(47,8)$ & & \\
\hline No & $61(52,1)$ & $48(52,2)$ & & \\
\hline Taking photos & & & $<0,000 ; 1 ; 1$ & 0,$003 ; 0,960$ \\
\hline Yes & $67(57,3)$ & $53(57,6)$ & & \\
\hline No & $50(42,7)$ & $39(42,4)$ & & \\
\hline Video recording & & & 1,$430 ; 1 ; 0,232$ & 0,$092 ; 0,181$ \\
\hline Yes & $54(46,2)$ & $34(37,0)$ & & \\
\hline No & $63(53,8)$ & $58(63,0)$ & & \\
\hline Respondent's option & & & $<0,000 ; 1 ; 1(1)^{* * *}$ & 0,$018 ; 0,793$ \\
\hline Yes & $6(5,1)$ & $4(4,3)$ & & \\
\hline No & $111(94,9)$ & $88(95,7)$ & & \\
\hline \multicolumn{5}{|c|}{ * Each answer option is presented as a separate dichotomous variable } \\
\hline ** For $2 \times 2$ tables, the Yates continu & correction $\mathrm{w}$ & ied. & & \\
\hline
\end{tabular}


Table 3. Gender distribution of respondents' answers to the multivariate question "For you, a mobile phone is ..."

\begin{tabular}{|c|c|c|c|c|}
\hline Variable & $\begin{array}{l}\text { Men } \\
\text { N (\% within } \\
\text { category) }\end{array}$ & $\begin{array}{l}\text { Women } \\
\text { N (\% within } \\
\text { category) }\end{array}$ & $\chi 2 ;$ df; p-value* & $\begin{array}{l}\text { Cramer's V; } \\
\text { p-value }\end{array}$ \\
\hline Business communication tool & & & 0,$095 ; 1 ; 0,758 *$ & 0,$033 ; 0,638$ \\
\hline Yes & $87(74,4)$ & $71(77,2)$ & & \\
\hline No & $30(25,6)$ & $21(22,8)$ & & \\
\hline Personal communication tool & & & 4,$359 ; 1 ; 0,037 *$ & 0,$159 ; 0,022$ \\
\hline Yes & $97(82,9)$ & $86(93,5)$ & & \\
\hline No & $20(17,1)$ & $6(6,5)$ & & \\
\hline Emergency communication tool & & & 2,$174 ; 1 ; 0,140 *$ & 0,$112 ; 0,106$ \\
\hline Yes & $66(56,4)$ & $62(67,4)$ & & \\
\hline No & $51(43,6)$ & $30(32,6)$ & & \\
\hline Status symbol & & & 0,$296 ; 1 ; 0,586(0,505)^{* *}$ & 0,$087 ; 0,208$ \\
\hline Yes & $2(1,7)$ & $0(0)$ & & \\
\hline No & $115(98,3)$ & $92(100)$ & & \\
\hline Entertainment tool & & & 4,$260 ; 1 ; 0,039$ & 0,$156 ; 0,024$ \\
\hline Yes & $25(21,4)$ & $9(9,8)$ & & \\
\hline No & $92(78,6)$ & $83(90,2)$ & & \\
\hline
\end{tabular}

* For $2 \times 2$ tables, the Yates continuity correction was applied.

** If 1 or more cells have expected count less than 5 we applied Fisher's Exact Test. Data presented as p-level.

*** Each answer option is presented as a separate dichotomous variable.

Table 4. Gender distribution of respondents' answers

\begin{tabular}{|c|c|c|c|c|}
\hline & Men & Women & & \\
\hline Variable & $\begin{array}{l}N(\% \text { within } \\
\text { category })\end{array}$ & $\begin{array}{l}\text { N (\% within } \\
\text { category) }\end{array}$ & $\chi 2 ;$ df; p-value* & $\begin{array}{l}\text { Cramer's } \\
\text { p-value }\end{array}$ \\
\hline Do you use mobile Internet? & & & 0,$003 ; 1 ; 0,955 *$ & 0,$020 ; 0,776$ \\
\hline Yes & $104(88,9)$ & $82(90,1)$ & & \\
\hline No & $13(11,1)$ & $9(9,9)$ & & \\
\hline Do you use mobile communications at work? & & & 0,$001 ; 1 ; 0,975 *$ & 0,$020 ; 0,774$ \\
\hline Yes & $108(92,3)$ & $83(91,2)$ & & \\
\hline No & $9(7,7)$ & $8(8,8)$ & & \\
\hline $\begin{array}{l}\text { Do you use mobile Internet during business } \\
\text { hours? }\end{array}$ & & & 0,$226 ; 1 ; 0,635 *$ & 0,$044 ; 0,524$ \\
\hline Yes & $84(73,0)$ & $70(76,9)$ & & \\
\hline No & $31(27,0)$ & $21(23,1)$ & & \\
\hline How many SIM cards do you use? & & & 0,$336 ; 1 ; 0,562 *$ & 0,$051 ; 0,463$ \\
\hline 1 card & $80(69,0)$ & $67(73,6)$ & & \\
\hline More than 1 card & $36(31,0)$ & $24(26,4)$ & & \\
\hline
\end{tabular}


How long have you been using your mobile phone?

$\begin{array}{lll}\mathbf{1 - 1 0} \text { years } & 21(18,3) & 17(19,8) \\ \mathbf{1 1 - 2 0} \text { years } & 66(57,4) & 54(62,8) \\ >\mathbf{2 0} \text { years } & 28(24,3) & 15(17,4)\end{array}$

1,$396 ; 2 ; 0,498$

0,$083 ; 0,498$

$15(17,4)$

How much time do you spend daily talking on a cell phone?

$<1$ hour

1-2 hours

$>2$ hours

How much time do you spend daily using multimedia features (music, movies, games)?

$<1$ hour

1-2 hours

$>2$ hours
How much time do you spend daily on mobile Internet, including social networking?

$\begin{array}{lll}<\mathbf{1} \text { hour } & 75(68,2) & 58(65,9) \\ \mathbf{1 - 2} \text { hours } & 23(20,9) & 24(27,3) \\ >\mathbf{2} \text { hours } & 12(10,9) & 6(6,8)\end{array}$

1,$772 ; 2 ; 0,412$

0,$095 ; 0,412$

\begin{tabular}{ll}
$79(68,1)$ & $60(66,7)$ \\
$33(24,8)$ & $28(31,1)$ \\
$4(3,4)$ & $2(2,2)$ \\
\hline
\end{tabular}

13,872; 2; 0,001

0,$267 ; 0,001$

$75(68,8) \quad 78(90,7)$

$25(22,9) \quad 5(5,8)$

$9(8,3) \quad 3(3,5)$

Do you use the mobile Internet during

business hours to search for professionally

0,$640 ; 1 ; 0,424 *$

0,$068 ; 0,332$

valid information?

\begin{tabular}{|c|c|c|c|c|}
\hline Yes & $86(75,4)$ & $73(81,1)$ & & \\
\hline No & $28(24,6)$ & $17(18,9)$ & & \\
\hline $\begin{array}{l}\text { Do you have installed medical mobile } \\
\text { applications? }\end{array}$ & & & 0,$007 ; 1 ; 0,934 *$ & 0,$016 ; 0,823$ \\
\hline Yes & $55(48,2)$ & $42(56,7)$ & & \\
\hline No & $59(51,8)$ & $48(53,3)$ & & \\
\hline $\begin{array}{l}\text { Would you like to use a mobile application } \\
\text { that facilitates your professional } \\
\text { performance? }\end{array}$ & & & 0,$719 ; 1 ; 0,397 *$ & 0,$073 ; 0,293$ \\
\hline Yes & $101(88,6)$ & $76(83,5)$ & & \\
\hline No & $13(11,4)$ & $15(16,5)$ & & \\
\hline
\end{tabular}

* For $2 \times 2$ tables, the Yates continuity correction was applied.

** Proportion of cells with expected count less than 5 exceeds $20 \%$.

*** p-level less than 0,05 .

Answering a multiple answer question "What elements need to be included in the mobile application?" most respondents selected the options "clinical recommendations" $(83.9 \%)$ and "pharmaceuticals" $(83.9 \%)$. The next most popular options were ICD-10 (74.0\%) and "clinical assessment scales" $(58.3 \%) .41 .1 \%$ of respondents would like to include information on the approved criteria for the quality of care, and $10.9 \%$ added their version to the answers (Figure 1). The gender distribution of answers to this question is presented in Table 5. Statistically significant differences with a weak association between the variables were established only in the "clinical scale" variant. $59 \%$ of men consider their presence in a medical mobile application to be necessary, compared to $43.5 \%$ of women. 


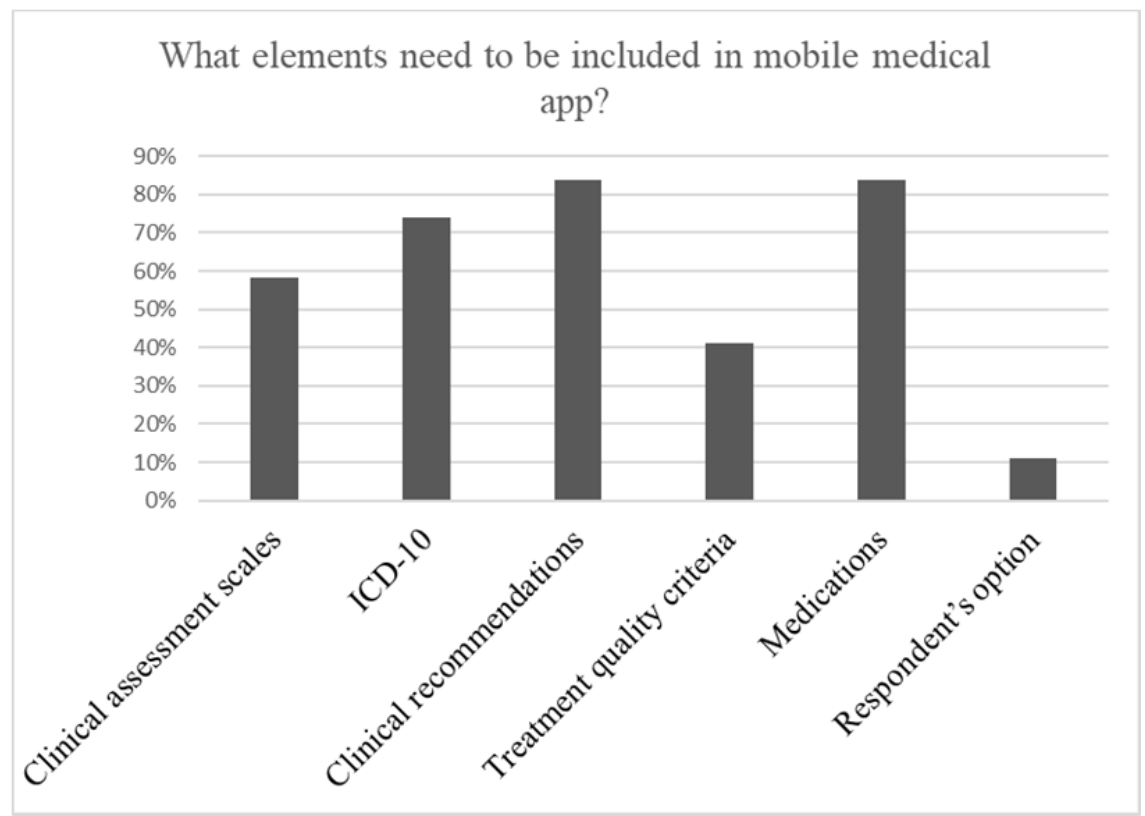

Figure 1. Answers to the question "What elements need to be included in the mobile application?"

Table 5. Gender distribution of respondents' answers to the multivariate question "What elements need to be included in the medical mobile application?" *

\begin{tabular}{|c|c|c|c|c|}
\hline Variable & $\begin{array}{l}\text { Men } \\
\text { N (\% within } \\
\text { category) }\end{array}$ & $\begin{array}{l}\text { Women } \\
\text { N (\% within } \\
\text { category) }\end{array}$ & $\chi 2 ;$ df; p-value** & Cramer's V; p-value \\
\hline Clinical assessment scales & & & 4,$355 ; 1 ; 0,037 * * *$ & 0,$154 ; 0,026$ \\
\hline Yes & $69(59,0)$ & $40(43,5)$ & & \\
\hline No & $48(41,0)$ & $52(56,5)$ & & \\
\hline ICD-10 & & & 2,$308 ; 1 ; 0,129$ & 0,$115 ; 0,095$ \\
\hline Yes & $84(71,8)$ & $56(60,9)$ & & \\
\hline No & $33(28,2)$ & $36(39,1)$ & & \\
\hline Clinical recommendations & & & 0,$442 ; 1 ; 0,506$ & 0,$057 ; 0,408$ \\
\hline Yes & $91(77,8)$ & $67(72,8)$ & & \\
\hline No & $26(22,2)$ & $25(27,2)$ & & \\
\hline Treatment quality criteria & & & 0,$427 ; 1 ; 0,513$ & 0,$055 ; 0,425$ \\
\hline Yes & $47(40,2)$ & $32(34,8)$ & & \\
\hline No & $70(59,8)$ & $60(65,2)$ & & \\
\hline Medications & & & 0,$662 ; 1 ; 0,416$ & 0,$068 ; 0,329$ \\
\hline Yes & $92(78,6)$ & $67(72,8)$ & & \\
\hline No & $25(21,4)$ & $25(27,2)$ & & \\
\hline Respondent's option & & & $<0,000 ; 1 ; 1$ & 0,$008 ; 0,910$ \\
\hline Yes & $12(10,3)$ & $9(9,8)$ & & \\
\hline No & $105(89,7)$ & $83(90,2)$ & & \\
\hline
\end{tabular}

* Each answer option is presented as a separate dichotomous variable.

** For $2 \times 2$ tables, the Yates continuity correction was applied.

*** p-level less than 0,05 . 


\section{Discussion}

Results of the study show that Russian doctors working in inpatient departments of addiction clinics quite actively use basic mobile communication technologies. Almost $90 \%$ of the sample studied used mobile Internet, and $30 \%$ used more than one SIM card. $94.8 \%$ of respondents use mobile phones as a means of communicating with colleagues, $30 \%$ use them as a means of communicating with patients, $83 \%$ described their device as a means of business communication, and $91.5 \%$ reported that they use mobile communications at work. Mobile Internet is used to search for professionally valid information by $77.8 \%$ of respondents. Almost half have installed medical mobile applications. At the same time, more than $85 \%$ want to have an application that helps them with their specialization. This level of mastering mobile technologies, as we think, provides for the readiness of Russian doctors working in inpatient departments of addiction clinics to use not only specialized mobile applications but also CDSS.

Prospects for using CDSS on mobile devices have been shown long ago. Divall noted that even PDA computers will allow transferring the clinical decision support system from a desktop computer directly to the clinical setting (Divall et al., 2013). Around the same time, a systematic review by Mickan stated that handheld computers are effectively used by healthcare professionals for easy and timely access to information, they allow for accurate and complete medical documentation, provide immediate access to CDSS and patient management systems based on the principles of evidence-based medicine and also contribute to the implementation of effective work practices (Mickan et al., 2014). A large-scale study by Carvalho also notes a generally positive attitude of anesthesiologists to the use of mobile medical applications (Carvalho et al., 2020).

The hypothesis about possible gender features in the use of mobile devices among doctors remained to a large extent unconfirmed. At the same time, the proportion of women who are looking for professionally valid information using their mobile phones (81.1\%) is greater than among men (75.4\%). Also, the proportion of women who have installed medical mobile applications exceeds that of men: $56.7 \%$ versus $48.2 \%$. On the other hand, $88.6 \%$ of men and $83.5 \%$ of women would like to use a mobile application that facilitates their professional performance. However, these differences were not statistically significant. The only exception was the use of multimedia, which was indicated by us in the "Results" section.

In answering the multivariate question "Do you use a mobile phone for ...", gender differences were identified in items that were not directly related to the professional activities of the respondents. Men more often than women use their smartphones to listen to music and watch video content (35.0\% versus $16.3 \%$ and $30.8 \%$ versus $15.2 \%)$.

When answering the multivariate question "A mobile phone is for you ...", twice as many men consider it as a means of entertainment: $21.4 \%$ versus $9.8 \%$. At the same time, women are more likely to perceive the phone as a means of everyday communication: $93.5 \%$ versus $82.0 \%$. Even though we did not find statistically significant differences in answers to the question "Do you use a mobile phone for games?" ( $10.3 \%$ of men answered affirmatively against $4.3 \%$ of women), we may assume that men more often perceive a smartphone as a means of entertainment and leisure.

This naturally correlates with the tendency of men to use the multimedia function on their smartphones that we have identified. The question arises: can this feature be used for greater adherence to mobile professional solutions, and, as a result, CDSS? This can be accomplished, for example, by implementing the well-established principles for the gamification of different healthcare activities, previously applied mainly to patients. Considering that these principles, according to (Abdul Rahim \& Thomas, 2017; Marques et al., 2017; Nadezhdin S.A., 2016; Sardi et al., 2017), began to be applied in the field of e-Health only in 2014, the process is at an early stage of its development and, undoubtedly, requires further research.

When answering the multivariate question "What elements need to be included in a mobile medical application ..." we did not find gender differences in the most common options: the need to include information on pharmaceuticals, providing access to clinical recommendations, ICD-10. (Note that, according to Tsugawa (Tsugawa et al., 2017), male doctors pay less attention to guidelines, which is not confirmed by our results). Statistically significant differences were demonstrated in the response option on the inclusion of clinical assessment scales in the application - this was more often suggested by men. It is difficult for us to interpret this difference - we can assume that female doctors are either better at using scales or male doctors want to formalize to greater extent information on the patient's condition. We would also like to note that a very small percentage of respondents gave their options in the "Respondent's option" field, which may indicate that practicing doctors are not well aware of what professionally valid information they can get from modern mobile applications. 


\subsection{Limitations of the Study}

The main limitation of this study was the relatively small sample size since the work was carried out in one, albeit a large, specialized medical institution with a specific set of medical specialties. In this regard, its results should be interpolated with care to health professionals in general. It cannot be ruled out that there are possible recall biases and inaccuracies associated with the desire to give a socially acceptable answer (social desirability bias) in any observational study, which may also to some extent affect the result (Althubaiti, 2016).

The issues raised in this article are too complex and multifaceted to be considered in one publication. The authors are aware that a few problems have remained only outlined or mentioned and hope to cover them in more detail in their future works.

\section{Conclusions}

Thus, we found no noticeable differences in the use of the smartphone for household and professional purposes between male and female doctors. Similar results, although exploring the use of mobile applications, were demonstrated in (Albrecht et al., 2017). The existing gender features that we have established are not global, categorically do not show the existence of the gender "digital divide" phenomenon and, rather, point to the possibility of using different methods to strengthen the commitment of various doctors to work with medical mobile applications.

It seems important to fill the knowledge gap associated with the insufficient study of other socio-demographic and occupational predictors affecting the use of professional mobile applications by health professionals of various specialties.

We would also recommend investigating whether the use of gamification can help doctors to utilize mobile applications in their routine professional activities, and how this approach can be adapted to different health professional groups.

\section{Competing Interests Statement}

The authors declare that there are no competing or potential conflicts of interest.

\section{References}

Abdul Rahim, M. I., \& Thomas, R. H. (2017). Gamification of Medication Adherence in Epilepsy. Seizure, 52, 11-14. https://doi.org/10.1016/j.seizure.2017.09.008

Albrecht, U.-V., Afshar, K., Illiger, K., Becker, S., Hartz, T., Breil, B., Wichelhaus, D., \& von Jan, U. (2017). Expectancy, usage and acceptance by general practitioners and patients: exploratory results from a study in the German outpatient sector. Digital Health, 3, 1-22. https://doi.org/10.1177/2055207617695135

Althubaiti, A. (2016). Information bias in health research: Definition, pitfalls, and adjustment methods. Journal of Multidisciplinary Healthcare, 9, 211-217. https://doi.org/10.2147/JMDH.S104807

Carvalho, H., Verdonck, M., Forget, P., \& Poelaert, J. (2020). Acceptance of mHealth among health professionals: A case study on anesthesia practitioners. BMC Anesthesiology, 20(1). https://doi.org/10.1186/s12871-020-00958-3

Divall, P., Camosso-Stefinovic, J., \& Baker, R. (2013). The use of personal digital assistants in clinical decision making by health care professionals: A systematic review. Health Informatics Journal, 19(1), 16-28. https://doi.org/10.1177/1460458212446761

Hargittai, E. (2003). The Digital Divide and What To Do About It. In Jones D.C. (Ed.), New Economy Handbook (New Economy Handbook, pp. 822-841). Academic Press. http://www.eszter.com/papers/c04-digitaldivide.html

Hong, Y. A., Zhou, Z., Fang, Y., \& Shi, L. (2017). The digital divide and health disparities in China: Evidence from a national survey and policy implications. Journal of Medical Internet Research, 19(9). https://doi.org/10.2196/jmir.7786

Jones, T. L., Baxter, M., \& Khanduja, V. (2013). A quick guide to survey research. Annals of the Royal College of Surgeons of England, 95(1), 5-7. https://doi.org/10.1308/003588413X13511609956372

Khairat, S., Marc, D., Crosby, W., \& al Sanousi, A. (2018). Reasons for physicians not adopting clinical decision support systems: Critical analysis. JMIR Medical Informatics, 20(4). https://doi.org/10.2196/medinform.8912

Marques, R., Gregório, J., Pinheiro, F., Póvoa, P., Mira Da Silva, M., \& Lapão, L. V. (2017). How can information 
systems provide support to nurses' hand hygiene performance? Using gamification and indoor location to improve hand hygiene awareness and reduce hospital infections. BMC Medical Informatics and Decision Making, 17:15. https://doi.org/10.1186/s12911-017-0410-z

Mickan, S., Atherton, H., Roberts, N. W., Heneghan, C., \& Tilson, J. K. (2014). Use of handheld computers in clinical practice: A systematic review. BMC Medical Informatics and Decision Making, 14(1). https://doi.org/10.1186/1472-6947-14-56

Nadezhdin A.V. (2018). Sistema informacionno-tekhnicheskoj podderzhki klinicheskogo nauchnogo issledovaniya. [IT-Support System for Clinical Research]. Narkologia, 17(8), 33-39. https://doi.org/10.25557/1682-8313.2018.08.33-39

Nadezhdin S.A. (2016). Metody global'nogo informacionnogo kontrolya kak sposob optimizacii sistemy medicinskogo strahovaniya [Global Information Surveillance Methods as a Way to Optimize Health Insurance System]. Narkologia, 15(3), 78-83.

O’Sullivan, D., Fraccaro, P., Carson, E., \& Weller, P. (2014). Decision time for clinical decision support systems. Clinical Medicine, 14(4), 338-341.

Rea L. M., \& Parker R. A. (2014). Designing and Conducting Survey Research A Comprehensive Guide. John Wiley \& Sons.

Roter, D. L., Hall, J. A., \& Aoki, Y. (2002). Physician Gender Effects in Medical Communication A Meta-analytic Review. JAMA, 177(2), 756-764. http://jama.jamanetwork.com/

Sardi, L., Idri, A., \& Fernández-Alemán, J. L. (2017). A systematic review of gamification in e-Health. Journal of Biomedical Informatics, 71, 31-48. https://doi.org/10.1016/j.jbi.2017.05.011

Shiferaw, K. B., \& Mehari, E. A. (2019). Internet use and eHealth literacy among health-care professionals in a resource-limited setting: A cross-sectional survey. Advances in Medical Education and Practice, 10, 563-570. https://doi.org/10.2147/AMEP.S205414

Skolka, M., Lehman, E., Khalid, M., \& Hennrikus, E. (2020). Physician characteristics correlate with hospital readmission rates. Medicine, 99(10), e19363. https://doi.org/10.1097/MD.0000000000019363

Tsugawa, Y., Jena, A. B., Figueroa, J. F., Orav, E. J., Blumenthal, D. M., \& Jha, A. K. (2017). Comparison of hospital mortality and readmission rates for Medicare patients treated by male vs female physicians. JAMA Internal Medicine, 177(2), 206-213. https://doi.org/10.1001/jamainternmed.2016.7875

WHA 71.726 May 2018. (n.d.). Digital health.

WHO. (2019). Recommendations on digital interventions for health system strengthening.

Yagos, W. O., Tabo Olok, G., \& Ovuga, E. (2017). Use of information and communication technology and retention of health workers in rural post-war conflict Northern Uganda: Findings from a qualitative study. BMC Medical Informatics and Decision Making, 17(1). https://doi.org/10.1186/s12911-016-0403-3 
Appendix 1. Non-Standardized anonymous self-questionnaire

Dear colleague! We ask you to participate in an anonymous survey and answer the questionnaire. This survey will help us to get acquainted with the target audience and find out the demands for the development of a mobile application ("assistant" of an addiction doctor)

Thank you in advance for your cooperation.

\begin{tabular}{|c|c|}
\hline \multirow{2}{*}{ Your gender } & Male \\
\hline & Female \\
\hline \multirow{5}{*}{ Your age } & $20-30$ \\
\hline & $31-40$ \\
\hline & $41-50$ \\
\hline & $51-60$ \\
\hline & Over 60 \\
\hline \multirow{2}{*}{ You are a department head } & Yes \\
\hline & No \\
\hline \multirow{5}{*}{ You are } & Addiction doctor \\
\hline & Psychotherapist \\
\hline & Psychiatrist \\
\hline & Doctor of another speciality \\
\hline & Resuscitation Anesthetist \\
\hline \multirow{2}{*}{ Do you use cell phone? } & Yes \\
\hline & No \\
\hline \multirow{2}{*}{ Do you use mobile Internet? } & Yes \\
\hline & No \\
\hline \multirow{3}{*}{ Your mobile phone operating system is } & Android \\
\hline & iOS \\
\hline & Other \\
\hline \multirow{2}{*}{ Do you use mobile communications at work? } & Yes \\
\hline & No \\
\hline \multirow{2}{*}{ How many SIM cards do you use? } & 1 \\
\hline & More than 1 \\
\hline \multirow{3}{*}{ How long have you been using your mobile phone? } & $1-10$ years \\
\hline & $11-20$ years \\
\hline & $>20$ years \\
\hline \multirow{7}{*}{$\begin{array}{l}\text { Do you use your mobile phone for... } \\
\text { (Multivariate question) }\end{array}$} & Communication with colleagues \\
\hline & Communication with clients \\
\hline & $\begin{array}{l}\text { Communication with relatives } \\
\text { and friends }\end{array}$ \\
\hline & $\begin{array}{l}\text { Search for information on the } \\
\text { Web }\end{array}$ \\
\hline & Social Media Communication \\
\hline & Listening to music \\
\hline & Playing games \\
\hline
\end{tabular}




\begin{tabular}{|c|c|}
\hline & Watching videos \\
\hline & Reading texts \\
\hline & Taking photos \\
\hline & Video recording \\
\hline & Respondent's option \\
\hline & Business communication tool \\
\hline & Personal communication tool \\
\hline For you, a monte prone is ... & Emergency communication tool \\
\hline & Status symbol \\
\hline & Entertainment tool \\
\hline & $<1$ hour \\
\hline How much time do you spend daily talking on a cell phone? & $1-2$ hours \\
\hline & $>2$ hours \\
\hline & $<1$ hour \\
\hline $\begin{array}{l}\text { How much time do you spend daily using multimedia features (music, } \\
\text { movies games)? }\end{array}$ & $1-2$ hours \\
\hline & $>2$ hours \\
\hline & $<1$ hour \\
\hline $\begin{array}{l}\text { How much time do you spend daily on mobile Internet, including social } \\
\text { netwarking? }\end{array}$ & $1-2$ hours \\
\hline & $>2$ hours \\
\hline 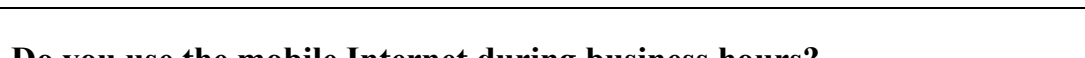 & Yes \\
\hline Do you use the monolie internet auring ousiness nours? & No \\
\hline Do you use the mobile Internet during business hours to search for & Yes \\
\hline professionally valid information? & No \\
\hline 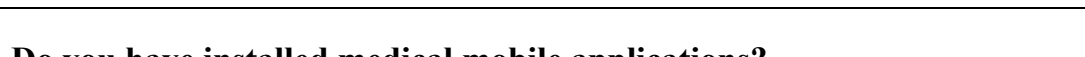 & Yes \\
\hline Do you have installed medical mobile applications? & No \\
\hline Would you like to use a mobile application that facilitates your & Yes \\
\hline professional performance? & No \\
\hline $\begin{array}{l}\text { What elements need to be included in the medical mobile application? } \\
\text { (Multivariate question) }\end{array}$ & Clinical assessment scales \\
\hline & ICD-10 \\
\hline & Clinical recommendations \\
\hline & Treatment quality criteria \\
\hline & Medications \\
\hline & Respondent's option \\
\hline
\end{tabular}

\section{Copyrights}

Copyright for this article is retained by the author(s), with first publication rights granted to the journal.

This is an open-access article distributed under the terms and conditions of the Creative Commons Attribution license (http://creativecommons.org/licenses/by/4.0/). 